\title{
Synthesis of novel porous tannin-phenol-formaldehyde cation exchange resin from Terminalia arjuna (Kumbuk)
}

\author{
L.D. Sumathirathne ${ }^{1}$ and L. Karunanayake $e^{1,2^{*}}$ \\ ${ }^{1}$ Department of Chemistry, Faculty of Applied Sciences, University of Sri Jayewardenepura, Gangodawila, Nugegoda. \\ ${ }^{2}$ Center for Advanced Material Research, Faculty of Applied Sciences, University of Sri Jayewardenepura, Gangodawila, Nugegoda.
}

Revised: 25 November 2016; Accepted: 19 January 2017

\begin{abstract}
Natural tannins have a high affinity to absorb metal ions, proteins and some other biomolecules. In this study, tannins extracted from Terminalia arjuna (Kumbuk) were used to synthesise renewable tannin-phenol-formaldehyde resin systems and a porous modified resin system. A series of resin systems was synthesised by varying the incorporated phenol content. The ion exchange capacities of the resins produced were studied and the resin with the highest ion exchange capacity was selected. It was sulfonated to increase the properties further. A monovalent cation, $\mathrm{Na}^{+}$was used to estimate the adsorption properties of both sulfonated and unsulfonated resin systems. Solubility and swelling properties of the resins were measured to check their applicability as an ion exchanger in aqueous media at different $\mathrm{pH}$ values. Fourier transform infrared spectroscopy (FTIR) analysis was carried out to characterise the synthesised resins. Scanning electronic microscopic (SEM) images were obtained to study the morphology of the resins produced. Sulfonated tannin-phenolformaldehyde resin with the tannin/phenol ratio of 1:1 showed the highest adsorption capacity for the metal ion used $\left(\mathrm{Na}^{+}\right)$, which was $1.552 \mathrm{meq} / \mathrm{g}$.
\end{abstract}

To increase the surface area and to gain an efficient flow rate, a porous tannin-phenol-formaldehyde resin system was prepared. Synthesis was carried out using hexamethylenetetramine as both the cross linker and the catalyst. Coconut oil was used as the porogenic agent to create the porous structure through emulsion templating process. Synthesised porous resin contains $\mu \mathrm{m}$ and $\mathrm{nm}$ scale porous structures.

Keywords: Cation exchange resin, FTIR, porous resin, SEM, sulfonation, tannin of Terminalia arjuna.

\section{INTRODUCTION}

Common metal removal methods are technically complicated, inefficient or costly in meeting the discharge standards for industrial effluent (Yu et al., 2008). Although ion exchange is more effective, a high capital expenditure is usually required for such systems. Hence, producing a resin based on natural materials is more economically viable (Yu et al., 2008).

The use of tannin based compounds as ion adsorbents have been reported due to the affinity of tannin towards various cations (Mitra et al., 1991). Randall (1977) examined the suitability of various barks as ion exchange substrates. Although tannin can adsorb ions, its high solubility in water was found to be a constraint to use tannin as an adsorbent in applications such as ion exchange resins. This problem can be overcome by polymerising it with formaldehyde to form polymers or copolymers (Arasaretnam \& Karunanayake, 2010). Garro Galvez et al. (1997) have studied the possibility of utilising Caesalpinia spinosa (Tara) tannin in the manufacture of wood adhesives. Thermosetting wood adhesive resins from valonia and mimosa were developed and characterised to remove various heavy metals by Ozacar et al. (2006).

Simple tannin formaldehyde resins (TFRs) possess a lower ion exchange capacity (IEC), and in order to produce a resin with better IEC, introduction of functional groups to the resin is needed (Mitra et al., 1991). Mitra et al. (1991) have extracted condensed tannins from spruce, mimosa, and radiata pine bark and reacted these with formaldehyde to have tannin formaldehyde resins with a lower cation exchange capacity. They have also modified tannin resins with different functional groups, and sulfonation of the resultant resin matrix was found to be very effective. Mitra et al. (1991) have developed

\footnotetext{
*Corresponding author (laleenk@gmail.com)
} 
sulfonated crosslinked tannin formaldehyde resins and tannin-phenol-formaldehyde ter-polymer resins as stable and reusable cation exchangers. They have found that the introduction of phenol units into the tannin formaldehyde matrix increased the available sites for sulfonation. Tannins extracted from Terminalia chebula (Aralu) were used by Arasaretnam and Karunanayake (2010) to synthesise tannin-phenol-formaldehyde resins (TPFR). They (Arasaretnam \& Karunanayake, 2010) produced ion exchange resins with different tannin to phenol ratios and sulfonated these to improve the properties further. The resin with $1: 0.5$ tannin to phenol ratio showed the highest IEC for all metal ions.

Porous resins were invented as a solution for slow kinetic and low IEC in typical ion exchangers. Kunin et al. (1962) developed a macroreticuler ion exchanger, Amberlyst 15, which is entirely different from conventional homogeneous gels. Ortiz-Palacios et al. (2008) synthesised macroporous resins with specific surface areas produced by suspension polymerisation with 4-vinylpyridine (4VP) and divinylbenzene (DVB) and various proportions of porogens. When used to remove $\mathrm{Cr}^{+6}$ in water samples they have shown high selectivity, fast adsorption kinetics and high removal capability at $\mathrm{pH}$ 6.5. Zhang and Sun (2001) developed a biporous anion exchange resin for protein chromatography incorporating solid granules and solvents as the porogenic medium.

Szczurek et al. (2014) synthesised an environmental friendly porous monolith using natural condensed tannins. Synthesis of the new carboHIPE was carried out by using sunflower oil, tannin solution and ethoxylated castor oil as the porogenic agent, external phase and surfactant, respectively (Szczurek et al., 2014). The use of tannins extracted from Terminalia arjuna (Kumbuk) in tannin-phenol-formaldehyde synthesis has not been reported. In this study, Kumbuk tannins were used to synthesise environmental friendly sulfonated TPFR and modified porous TPFR. The emulsion templating method was followed to synthesise the modified resin and coconut oil was used as the porogenic agent.

\section{METHODOLOGY}

\section{Extraction of tannins from dried Kumbuk bark}

The bark layer of Terminalia arjuna (Kumbuk) (thickness about $1 \mathrm{~cm}$ ) was collected from the Anuradhapura area of Sri Lanka. After cleaning, the dried Kumbuk bark was finely ground to reduce particle size.
Initially, the powdered sample was extracted using hexane at $68^{\circ} \mathrm{C}$ for $1 \mathrm{~h}$, and then extracted using petroleum ether at $45^{\circ} \mathrm{C}$ for $1 \mathrm{~h}$ to remove nonpolar compounds. Finally, the ground bark sample was extracted using methanol at $70{ }^{\circ} \mathrm{C}$ for $2 \mathrm{~h}$. The methanol extract was filtered and concentrated using a rotary evaporator under reduced pressure. The resulted dark brown coloured viscous liquid was heated to obtain tannins by evaporating the solvent in a water bath at $80^{\circ} \mathrm{C}$.

\section{Identification of tannin types}

Ferric tests, acid butanol tests and nitrous acid tests were used in order to confirm the presence of phenolic compounds, condensed tannins and ellagitannins, respectively.

\section{Determination of total polyphenolic content}

Total polyphenolic content was determined using the folin-ciocalteau method. Commercially available folinciocalteau reagent was diluted with an equal volume of distilled water. Then $10.00 \mathrm{~cm}^{3}$ from that solution was pipetted out to a $100.00 \mathrm{~cm}^{3}$ volumetric flask and made up to the mark with distilled water. A series of gallic acid solutions of 50, 55, 60, 65, 70 and 75 ppm were prepared as standards. Aliquots $\left(1.00 \mathrm{~cm}^{3}\right)$ of the gallic acid standards were poured into 6 test tubes. Then $5.00 \mathrm{~cm}^{3}$ of diluted folin-ciocalteau reagent was added to the solutions and allowed to react for $6-8 \mathrm{~min}$. Thereafter, $4.00 \mathrm{~cm}^{3}$ of sodium carbonate solution $[7.5 \%(\mathrm{w} / \mathrm{w})]$ was added and the contents of the test tubes were mixed well. The test tubes were covered with aluminium foil and kept at room temperature for $2 \mathrm{~h}$. The absorbance measurements were taken at $750 \mathrm{~nm}$ using a colourimeter. The absorbances of the prepared tannin samples were also measured following the same procedure. The total polyphenolic content in the extracted crude tannin sample was calculated using a calibration plot.

\section{Preparation of TFR and TPFR}

For the preparation of TFR, a $20.000 \mathrm{~g}$ sample of solidified tannin extract was dissolved in $50.00 \mathrm{~cm}^{3}$ of deionised water in an Erlenmeyer flask. About $10.00 \mathrm{~cm}^{3}$ of methanol was also added to the flask at room temperature. The $\mathrm{pH}$ of the reaction mixture was adjusted to 10 using a solution of $\mathrm{NaOH}[33 \%(\mathrm{w} / \mathrm{w})]$. The required amount of formaldehyde solution [37\% $(\mathrm{w} / \mathrm{w})$ ] was added dropwise at $40{ }^{\circ} \mathrm{C}$ while stirring until the gel formation occurred. The mixture was brought to $80{ }^{\circ} \mathrm{C}$ using a water bath and kept at $80{ }^{\circ} \mathrm{C}$ for $1 \mathrm{~h}$. 
The resultant mixture was allowed to cool and harden. It was neutralised using a dilute $\mathrm{HCl}(0.1 \mathrm{M})$ solution. The resin produced was washed with hot deionised water and filtered using vacuum filtration to remove unnecessary reagents. The resin was ground and oven-dried at $100{ }^{\circ} \mathrm{C}$ for $1 \mathrm{~h}$ for further crosslinking. It was sieved through a 20-mesh sieve to get uniform particle size. Finally, the resin was cooled and stored in a desiccator.

The same procedure was followed to synthesise TPFR while incorporating various amounts of phenol to the initial water tannin mixture.

\section{Sulfonation of the resins}

A sample of TFR or TPFR (10.300 g) prepared using Kumbuk tannin was refluxed with $25.00 \mathrm{~cm}^{3}$ of $\mathrm{H}_{2} \mathrm{SO}_{4}$ [98\% (w/w)] at $105{ }^{\circ} \mathrm{C}$ for $6 \mathrm{~h}$ in a paraffin bath to obtain the sulfonated resin. The sulfonated resin was allowed to cool, washed with hot deionised water and vacuum filtered to remove the residual free $\mathrm{H}_{2} \mathrm{SO}_{4}$. Then the resin was neutralised and converted to its $\mathrm{Na}^{+}$form using $250.00 \mathrm{~cm}^{3}$ of $1.0 \mathrm{M} \mathrm{NaCl}$ solution. The resin was washed with deionised water to remove excess $\mathrm{NaCl}$, dried in an oven at $105^{\circ} \mathrm{C}$ and allowed to cool in a desiccator.

\section{Preparation of modified resin}

Initially, $20.000 \mathrm{~g}$ of tannin, $10.000 \mathrm{~g}$ of phenol, and $30.00 \mathrm{~mL}$ of distilled water were mixed in a $250.00 \mathrm{~mL}$ beaker and $0.700 \mathrm{~g}$ of pure $p$-toluene sulfonic acid (PTSA) was added to it as a catalyst. It was then mixed using a mechanical mixer at $250 \mathrm{rpm}$ for $20 \mathrm{~min}$. About $0.420 \mathrm{~g}$ $[1.4 \%(\mathrm{w} / \mathrm{w})]$ of Wettam solution was added as a nonionic emulsifier and it was mixed for further $20 \mathrm{~min}$ at $250 \mathrm{rpm}$ to ensure homogeneity of the emulsion.

As the second part of the procedure, $50.00 \mathrm{~mL}$ of coconut oil was continuously added dropwise at a rate of 44 drops per min while stirring at $250 \mathrm{rpm}$. After half of the volume of coconut oil was added, $5.022 \mathrm{~g}$ [40\%(w/w)] of hexamethylenetetramine (hexamine) was added as a crosslinker to the emulsion. The mixing speed was increased to $900 \mathrm{rpm}$ for $30 \mathrm{~s}$ to increase mixing of hexamine, and reduced to $250 \mathrm{rpm}$ before the remaining oil was added dropwise. After adding the total volume of oil, the mixture was mixed for an additional $10 \mathrm{~min}$ at the same speed.

The resulting light brown coloured viscous emulsion was poured into a Petri dish and covered with an aluminium foil. It was allowed to cure in a ventilated oven at $80{ }^{\circ} \mathrm{C}$ for 20 h. A dark brown coloured tannin-phenol- formaldehyde porous resin was formed and the excess oil fraction was removed. The resin was allowed to cool at room temperature in a desiccator before being cut into small cubes and inserted to a thimble. It was refluxed in a Soxhlet extractor using acetone as the solvent for $7 \mathrm{ds}$ to remove the coconut oil completely. It was allowed to cool and stored in a desiccator.

\section{Determination of IEC for monovalent cations}

About $5.000 \mathrm{~g}$ of the $\mathrm{Na}^{+}$forms of sulfonated and unsulfonated resins were allowed to hydrate in deionised water for several minutes before being packed into a burette-type column using deionised water. In this study, the IEC of the monovalent cation, $\mathrm{Na}^{+}$was determined. The $\mathrm{Na}^{+}$form of the sulfonated and unsulfonated resins were converted to $\mathrm{H}^{+}$form using $0.1 \mathrm{M} \mathrm{HCl}$ solution as the influent. The resin columns were then washed with deionised water until the output was free from excess $\mathrm{H}^{+}$ions. A $0.1 \mathrm{M} \mathrm{NaCl}$ solution was allowed to pass through the resin columns at a rate of $3 \mathrm{~cm}^{3} \mathrm{~min}^{-1}$. The effluent was collected and $\mathrm{H}^{+}$ions in the effluent were estimated by titrating with a $0.1 \mathrm{M} \mathrm{NaOH}$ solution using phenolphthalein as the indicator to calculate IEC.

\section{Scanning electron microscopic (SEM) studies}

The resins were sputtered with gold and images were obtained using a scanning electron microscope (Hitachi SU6600). The images were analysed and the pore diameter was calculated using Image $\mathrm{J}$ software.

\section{RESULTS AND DISCUSSION}

\section{Synthesis of tannin-phenol-formaldehyde resins (TPFR)}

Although the extracted tannin was soluble in distilled water, TFR and TPFR did not dissolve. By changing the tannin/phenol ratio, different resin systems were obtained and their yields are shown in Table 1.

\section{Synthesis of porous modified resins}

Coconut oil is a commonly used vegetable oil produced in Sri Lanka. Hence, in modified resin synthesis, instead of sunflower oil, coconut oil was used. When considering the fatty acid composition, coconut oil contains a higher percentage of saturated fatty acids than sunflower oil (Table 2). As unsaturated fatty acids are more susceptible to oxidative reactions, according to fatty acid activity coconut oil is expected to be less reactive than sunflower oil. Therefore, we can assume that the use of coconut oil 
as the porogenic solvent instead of sunflower oil does not lead to side reactions. As the reaction mixture is heated only up to $80^{\circ} \mathrm{C}$, the relatively low smoke point will also not affect the process.

Hexamine is considered as a hardener in industry. In this study, hexamine was used as the crosslinker in place of formaldehyde. Hexamine releases formaldehyde to the polymerisation, while releasing $\mathrm{NH}_{3}$ as a catalyst to the reaction. Hence, we can assume that $-\mathrm{CH}_{2}$ - linkages will be formed in the polymerisation reaction as in other TPFRs discussed before. However, in the fourier transform infrared spectroscopy (FTIR) spectrum of the modified resin, there were peaks that can be assigned to $\mathrm{C}-\mathrm{N}$ bonds at $1239 \mathrm{~cm}^{-1}$. According to previous studies, $-\mathrm{CH}_{2}-\mathrm{NH}-\mathrm{CH}_{2}-$ linkages can occur during the tannin hexamine polymerisation (Pena et al., 2009; Moubarik et al., 2010; Zhu et al., 2013) (Figure 1).

Table 1: Yield of resin with different tannin: phenol weight ratios

\begin{tabular}{lcccc}
\hline Label of resin & $\begin{array}{c}\text { Crude tannin } \\
\text { weight }(\mathrm{g})\end{array}$ & $\begin{array}{c}\text { Added phenol } \\
\text { weight }(\mathrm{g})\end{array}$ & $\begin{array}{c}\text { Required formaldehyde } \\
\text { volume for gel } \\
\text { formation }(\mathrm{mL})\end{array}$ & $\begin{array}{c}\text { Yielded resin } \\
\text { weight }(\mathrm{g})\end{array}$ \\
\hline KRT1P0 & 2.500 & 0.000 & 0.65 & 2.295 \\
KRT1P0.25 & 2.500 & 0.625 & 0.70 & 2.305 \\
KRT1P0.5 & 2.500 & 1.250 & 0.90 & 2.350 \\
KRT1P0.75 & 2.500 & 1.875 & 1.00 & 2.602 \\
KRT1P1 & 2.500 & 2.500 & 0.50 & 2.088 \\
\hline
\end{tabular}

Table 2: Chemical composition of coconut and sunflower oil

\begin{tabular}{lcccc}
\hline Type of oil & $\begin{array}{c}\text { Saturated } \\
\text { fatty acid } \%\end{array}$ & $\begin{array}{c}\text { Monounsaturated } \\
\text { fatty acid } \%\end{array}$ & $\begin{array}{c}\text { Polyunsaturated } \\
\text { fatty acid } \%\end{array}$ & $\begin{array}{c}\text { Smoke } \\
\text { point }\left({ }^{\circ} \mathrm{C}\right)\end{array}$ \\
\hline Coconut oil & 86 & 6 & 2 & 177 \\
Sunflower oil (high oleic) & 11 & 20 & 69 & 225 \\
& 12 & 84 & 4 & - \\
\hline
\end{tabular}

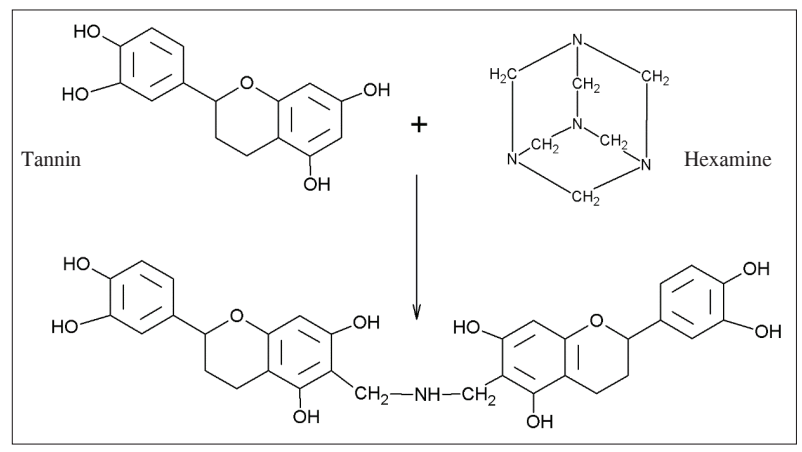

Figure 1: Possible reaction between tannin and hexamine (Moubarik et al., 2010)

According to literature, the new modified resin could be treated as an organic polyHIPE. As the modified resin started to float in the water filled burette, it was difficult to prepare a column to use in ion exchange studies. However, the low density of the resin indicates that it has a porous structure. In addition, when trying to pass a solvent through the modified resin system, it did not flow through, indicating that the porous structure is a closedcell type.

\section{Determination of IEC of resin systems}

The IECs obtained for unsulfonated resin systems with different tannin to phenol ratios and the IECs of sulfonated resin systems are shown in Table 3. The highest IEC was obtained for the resin labelled $\mathrm{KRT} 1 \mathrm{P} 1 \mathrm{SO}_{3} \mathrm{Na}$, which had a tannin/phenol ratio of 1:1.

The simple tannin formaldehyde resin that does not contain phenol (KRT1P0) showed the lowest IEC. It is due to the weak acidic character of the phenolic hydroxyl groups present in the resin (Arasaretnam \& Karunanayake, 2010). With increasing incorporation of phenol into the reaction mixture, the IEC increased as shown in Figure 2. 
Table 3: IEC values for different polyphenolic contents of sulfonated and unsulfonated resin systems

\begin{tabular}{|c|c|c|c|c|}
\hline \multirow[t]{2}{*}{ Label of resins } & \multirow[t]{2}{*}{$\begin{array}{l}\text { Tannin: phenol } \\
\text { (weight ratio) }\end{array}$} & \multirow{2}{*}{$\begin{array}{l}\text { Total polyphenolic } \\
\text { content in the } \\
\text { extract }(\%)\end{array}$} & \multicolumn{2}{|c|}{$\begin{array}{c}\mathrm{IEC} \mathrm{Na} / \mathrm{H}^{+} \\
(\mathrm{meq} / \mathrm{g})\end{array}$} \\
\hline & & & Cycle 1 & Cycle 2 \\
\hline KRT1P0 & $1: 0$ & 49.12 & 0.0500 & 0.0480 \\
\hline $\mathrm{KRT} 1 \mathrm{P} 0 \mathrm{SO}_{3} \mathrm{Na}$ & & & 0.0470 & 0.0430 \\
\hline KRT1P0.25 & $1: 0.25$ & 61.40 & 0.5446 & 0.5086 \\
\hline KRT1P0.5 & $1: 0.5$ & 73.68 & 0.5221 & 0.5182 \\
\hline $\mathrm{KRT} 1 \mathrm{P} 0.5 \mathrm{SO}_{3} \mathrm{Na}$ & & & 0.6940 & 0.6040 \\
\hline KRT1P0.75 & $1: 0.75$ & 85.96 & 0.5638 & 0.4938 \\
\hline KRT1P1 & $1: 1$ & 98.24 & 0.7993 & 0.7414 \\
\hline $\mathrm{KRT} 1 \mathrm{P} 1 \mathrm{SO}_{3} \mathrm{Na}$ & & & 1.5520 & 1.4000 \\
\hline
\end{tabular}

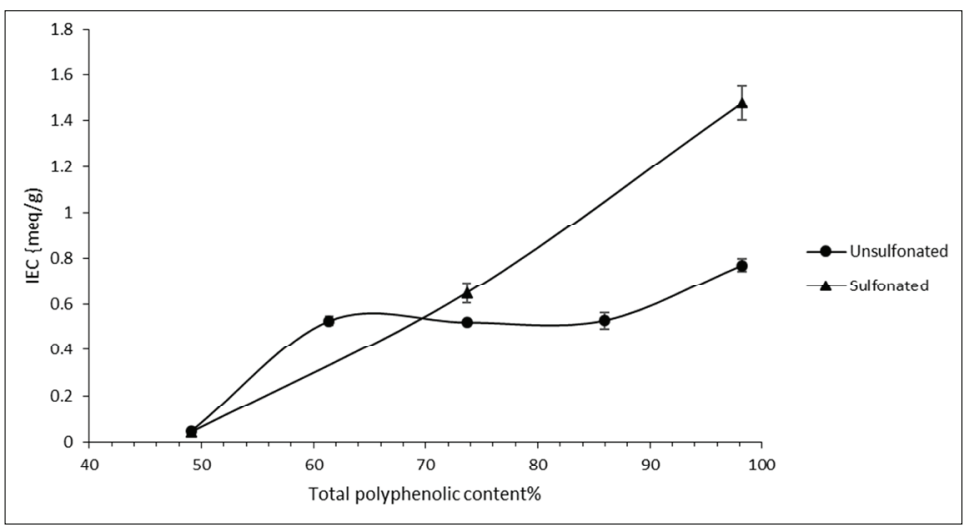

Figure 2: IEC of different resin systems with their total polyphenolic content

According to the studies of Arasaretnam and Karunanayake (2010), the highest IEC was measured in the resin with a $1: 0.5$ tannin to phenol ratio. However in this study, the highest value was shown for the resin with 1:1 tannin to phenol ratio (KRT1P1). It seems that an increase of phenol units in the TPFR system increases available ion exchange sites.

The introduction of strong acidic groups $\left(\mathrm{SO}_{3}^{-}\right)$to the TFR and TPFR systems using sulfonation has increased the IEC values significantly (Table 3 and Figure 2). However, according to Figure 2, the effect of sulfonation is much higher when the phenol content is high in the resin. Tannin formaldehyde resins without pure phenol groups restrict the sites for sulfonation because of the complex branched structure of the tannin molecules. Resins formed with pure phenolic bodies reduce the steric hindrance by separating the tannin molecules, providing more sites for sulfonation in both phenol and tannin molecules.

According to previous studies sulfonated resin system with $1: 0.5$ tannin to phenol ratio showed the highest IEC for monovalent cations $\left(\mathrm{H}^{+} / \mathrm{Na}^{+}\right)$(i.e. 0.6450 $\mathrm{meq} / \mathrm{g}$ ) (Arasaretnam \& Karunanayake, 2010). In this study, the KRT1P0.5 $\mathrm{SO}_{3} \mathrm{Na}$ resin system had a similar IEC of $0.6940 \mathrm{meq} / \mathrm{g}$. However, the highest IEC value of $1.5520 \mathrm{meq} / \mathrm{g}$ was shown for the sulfonated resin with 1:1 tannin:phenol ratio.

\section{FTIR analysis}

Figure 3 shows the FTIR spectra of dried Kumbuk bark and its tannin extract in the range of 640 to $3990 \mathrm{~cm}^{-1}$. The 
3550 to $3100 \mathrm{~cm}^{-1}$ broad absorption band corresponds to $-\mathrm{OH}$ bridging groups (Özacar et al., 2006) and the corresponding peak in the crude tannin sample is high in intensity compared to that of the dried bark sample. The $1600-1585 \mathrm{~cm}^{-1}$ and $1500-1400 \mathrm{~cm}^{-1}$ absorption bands can be attributed to aromatic skeletal vibrations, representing $\mathrm{C}=\mathrm{C}$ stretching (Steyermark, 1976). The tannin extract from the bark has a much stronger peak compared to that of the bark sample, showing that the tannin extract from the bark has a much higher concentration of aromatic compounds (Arasaretnam \& Karunanayake, 2010). The 1420 to $1330 \mathrm{~cm}^{-1}$ absorption band belongs to the $\mathrm{O}-\mathrm{H}$ in plane deformation (Steyermark, 1976). The peaks at $1340 \mathrm{~cm}^{-1}$ in the crude tannin extract and $1367 \mathrm{~cm}^{-1}$ in the dried bark sample can be assigned to $\mathrm{O}-\mathrm{H}$ in plane deformation. Again, the intensity of the band of crude tannin extract is stronger than the dried bark sample. The 1260 to $1000 \mathrm{~cm}^{-1}$ strong absorption band indicates $\mathrm{C}-\mathrm{O}$ stretching vibrations in alcohol and phenol (Steyermark, 1976). The absorption band at $1199 \mathrm{~cm}^{-1}$ can be assigned to C-O stretching vibration and it has a much higher intensity in the extracted crude tannin (Steyermark, 1976; Stuart, 2005; Arasaretnam \& Karunanayake, 2010).

Figure 4 shows a comparison of FTIR spectra of KRT1P1SO $\mathrm{S}_{3} \mathrm{Na}, \mathrm{KRT} 1 \mathrm{P} 0.5 \mathrm{SO}_{3} \mathrm{Na}$ and the corresponding tannin extract in the range of 660 to $3990 \mathrm{~cm}^{-1}$. The strong broad peaks at 1157 and $1143 \mathrm{~cm}^{-1}$ in KRT1P0.5SO $\mathrm{Na}$ and $\mathrm{KRT} 1 \mathrm{P}_{1} \mathrm{SO}_{3} \mathrm{Na}$ can be attributed to dimethylene ether linkages. The 840 to $730 \mathrm{~cm}^{-1}$ absorption bands can be assigned to the deformation vibration of $\mathrm{C}-\mathrm{H}$

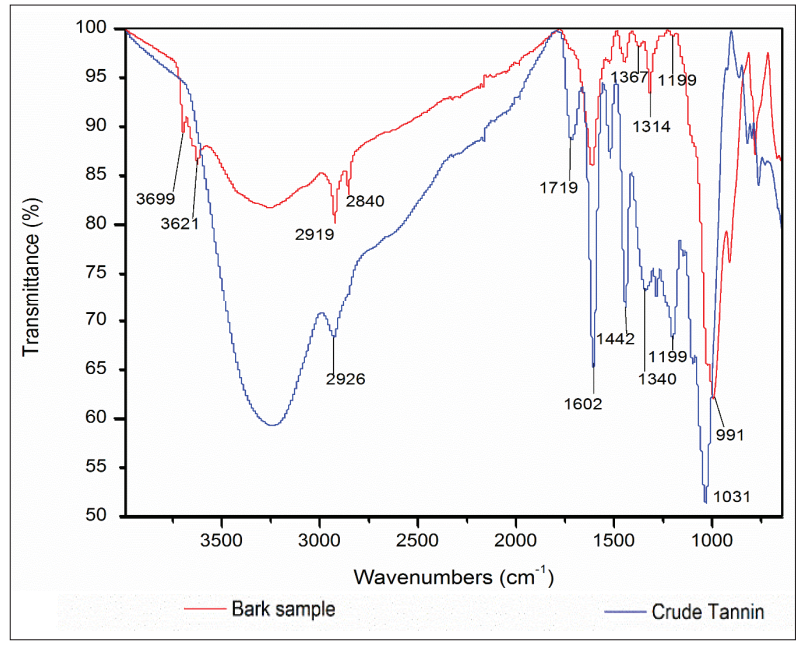

Figure 3: FTIR spectra of Kumbuk bark sample and its extracted tannin

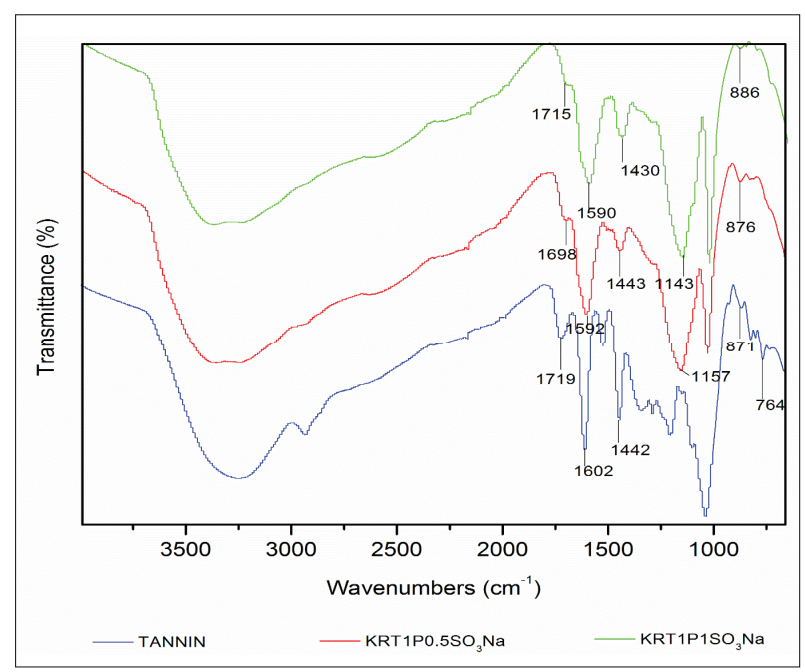

Figure 4: FTIR spectra of $\mathrm{KRT} 1 \mathrm{P} 1 \mathrm{SO}_{3} \mathrm{Na}, \mathrm{KRT} 1 \mathrm{P} 0.5 \mathrm{SO}_{3} \mathrm{Na}$ and tannin sample

bonds in benzene ring (Özacar et al., 2006). Although this bond does not participate in any chemical reaction during polymerisation, a decreased peak intensity can be observed in polymerised resin systems (KRT1 $\mathrm{P} 0.5 \mathrm{SO}_{3} \mathrm{Na}$, $\mathrm{KRT} 1 \mathrm{P}_{1} \mathrm{SO}_{3} \mathrm{Na}$ ) compared to that of the tannin sample. This may be due to volume contraction occurring during resin polymerisation. The 1500 to $1400 \mathrm{~cm}^{-1} \mathrm{C}=\mathrm{C}$ stretching band intensity clearly decreases in the resin spectra compared to that of the tannin sample. This reduction of the band implies that crosslinking reactions have occurred with the aromatic ring.

In the spectrum of sulfonated phenol-modified resin $\left(\mathrm{KRT} 1 \mathrm{P} 0.5 \mathrm{SO}_{3} \mathrm{Na}\right)$, there is a new peak that appears at $1157 \mathrm{~cm}^{-1}$ and this broad, intense peak can be attributed to $\mathrm{S}=\mathrm{O}$ groups. The peak appearing in the $3550-3500 \mathrm{~cm}^{-1}$ range, that can be assigned to phenolic $-\mathrm{OH}$ has been shifted from lower wave numbers $\left(3200 \mathrm{~cm}^{-1}\right)$ to higher wave numbers $\left(3350 \mathrm{~cm}^{-1}\right)$. Further, the appearance of a shoulder $\left(3200 \mathrm{~cm}^{-1}\right)$ can be seen in the sulfonated resin spectrum. The shoulder has close wave numbers to the $-\mathrm{OH}$ peak of tannins and unsulfonated resins, and indicates the presence of two different types of $-\mathrm{OH}$ groups. The peak around $3500 \mathrm{~cm}^{-1}$ can be assigned to free $-\mathrm{OH}$ groups. Hence, it can be concluded that sulfonation has liberated some of the hydrogen bonded -OH groups. It also shows that sulfonation has left some unaffected $-\mathrm{OH}$ groups represented by the shoulder around $3200 \mathrm{~cm}^{-1}$. This results show that the phenolated resin has been successfully sulfonated (Steyermark, 1976; Stuart, 2005; Pena et al., 2009; Arasaretnam \& Karunanayake, 2010). 
When comparing the spectrum of the modified resin with KRT1P1SO ${ }_{3} \mathrm{Na}$, similar basic features and a few different peaks are observed (Figure 5). The spectrum of the modified resin also shows the $-\mathrm{OH}$ strong broad peak with a small shoulder in $3500-3200 \mathrm{~cm}^{-1}$. The $2922 \mathrm{~cm}^{-1}$ absorption band can be attributed to $\mathrm{C}-\mathrm{H}$ and $-\mathrm{CH}_{2}$ vibrations of aliphatic hydrocarbon in the modified resin and it is weak in the other spectrum. The peak assigned to $\mathrm{C}-\mathrm{O}-\mathrm{C}$ aliphatic ether bonds of the KRT1P1SO $\mathrm{Na}$ resin was at $1143 \mathrm{~cm}^{-1}$. However, the corresponding peak in the modified resin was shifted to $1105 \mathrm{~cm}^{-1}$, with decreased peak intensity. Instead of the above peak, there was a new peak that arose at $1239 \mathrm{~cm}^{-1}$, that can be due to the presence of $\mathrm{C}-\mathrm{N}$ stretching coupled with the stretching of adjacent bonds in molecules (Steyermark, 1976; Pena et al., 2009). According to above comparison of FTIR spectrum, it can be assumed that the modified resin system contains $-\mathrm{CH}_{2}$ linkages formed by $\mathrm{C}-\mathrm{O}-\mathrm{C}$ bonds and also considerable amounts of $\mathrm{CH}_{2}-\mathrm{NH}-\mathrm{CH}_{2}$ linkages (Pena et al., 2009; Moubarik et al., 2010; Zhu et al., 2013)

\section{Scanning electron microscopic (SEM) image analysis}

According to SEM images of the original resin system in both $\mu \mathrm{m}$ and nm scale, it is difficult to observe a clear porous structure (Figure 6). However, it shows some heterogeneities and those can be due to high condensed and low condensed areas of the polymerised resin matrix.

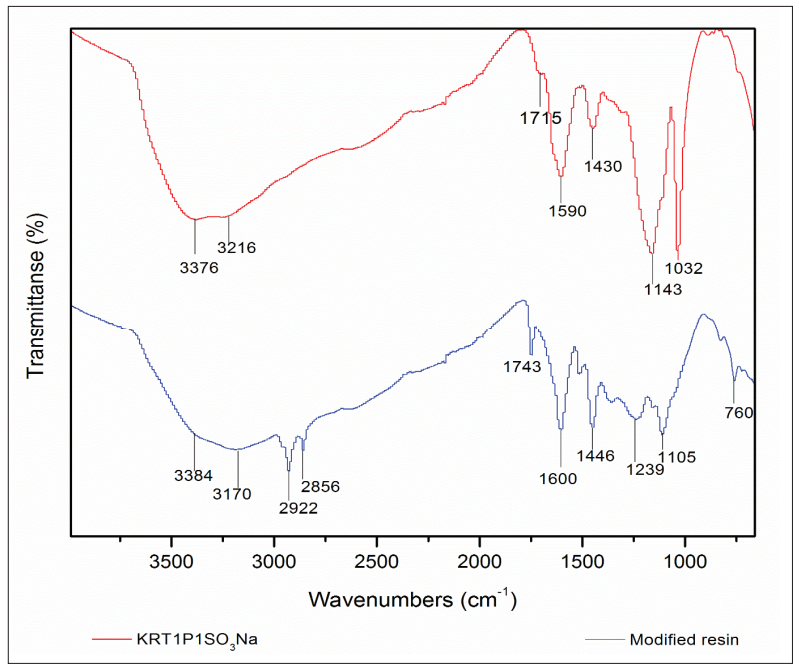

Figure 5: FTIR spectra of $\mathrm{KRT} 1 \mathrm{P} 1 \mathrm{SO}_{3} \mathrm{Na}$ and modified resin systems
In SEM images of the modified resin system [Figure 7 (a) to (f)], it can be clearly observed that the resin system contains $\mu \mathrm{m}$ and $\mathrm{nm}$ scale pores and also some heterogeneities. Figure 7 (a) provides evidence that the prepared porous resin system is composed of both closed cell and open cell structures. Figure 7 (b) is a closed cell structure while Figure 7(c) and (d) are open cell structures in both $\mu \mathrm{m}$ and $\mathrm{nm}$ scale.

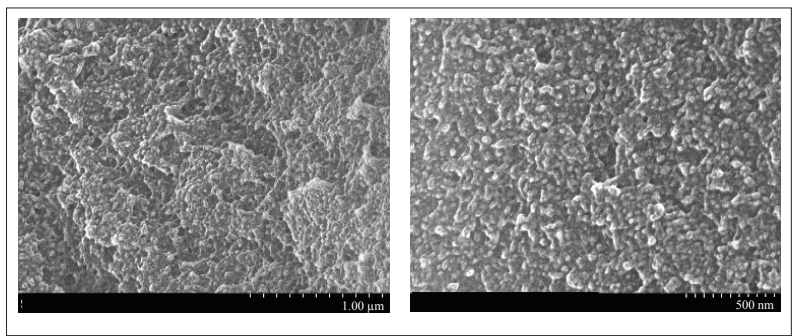

Figure 6: $\mathrm{SEM}$ images of $\mathrm{KRT} 1 \mathrm{P} 1 \mathrm{SO}_{3} \mathrm{Na}$ system (original resin) in $\mu \mathrm{m}$ and $\mathrm{nm}$ scale

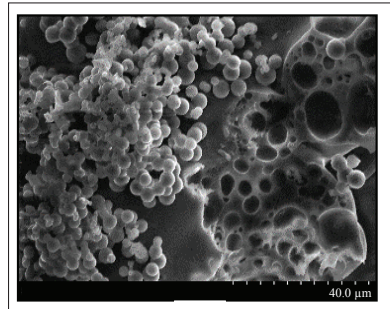

(a)

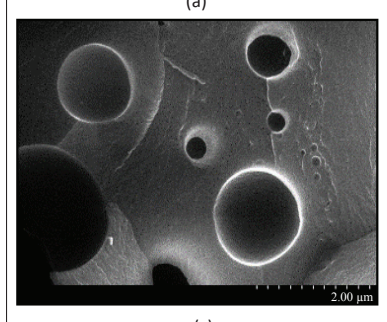

(c)

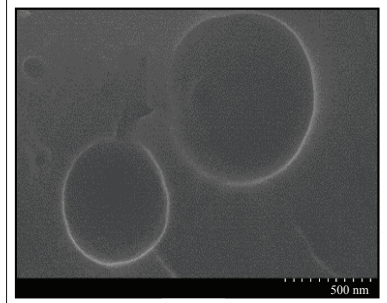

(e)

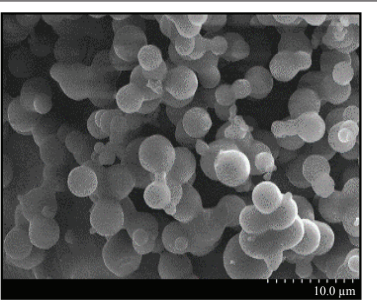

(b)

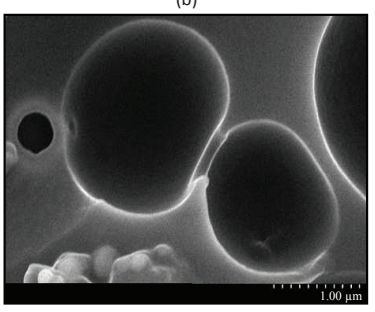

(d)

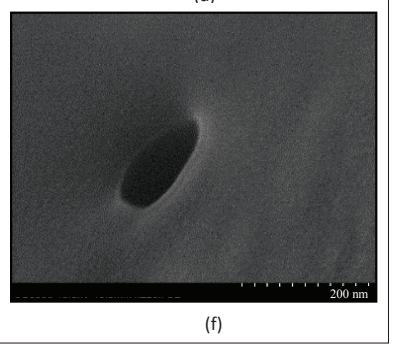

Figure 7: (a-f) SEM images of modified resin system in $\mu \mathrm{m}$ and $\mathrm{nm}$ scale 


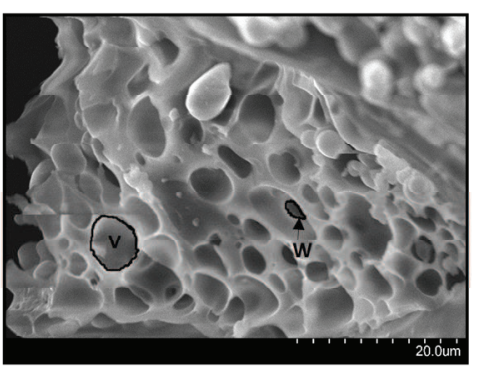

(a)

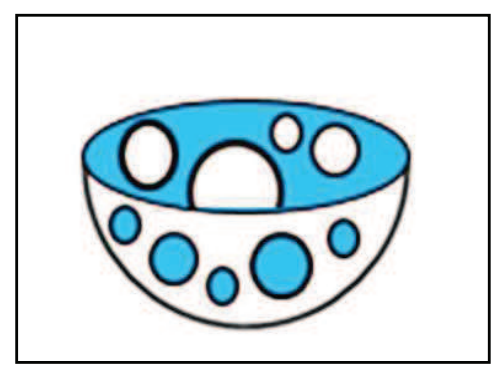

(b)

Figure 8: (a) SEM image of modified tannin-phenol-formaldehyde resin (V - void, W - window); (b) a cross section model of an open cell structure unit in a typical polyHIPE

As in Figure 8 (a), there are some large cells with open voids and embedded windows. These structures are similar to open cell structures of a typical polyHIPE. Closed cell structures can be considered as connected hollow spheres and their voids and windows are difficult to observe [Figure 7 (b)].

Figure 9 shows pore diameter distribution of the modified TPFR system. The histogram provides evidence that the modified resin contains both $\mu \mathrm{m}$ and $\mathrm{nm}$ scale pores. According to the histogram, a large proportion of the pores are in $\mu \mathrm{m}$ scale. However, a considerable amount of nm scale pore structures can also be seen.

According to literature, better porous resin systems with a fewer closed cell structures can be synthesised by increasing the fraction of oil used as the porogenic solvent. There are several factors that affect pore sizes,

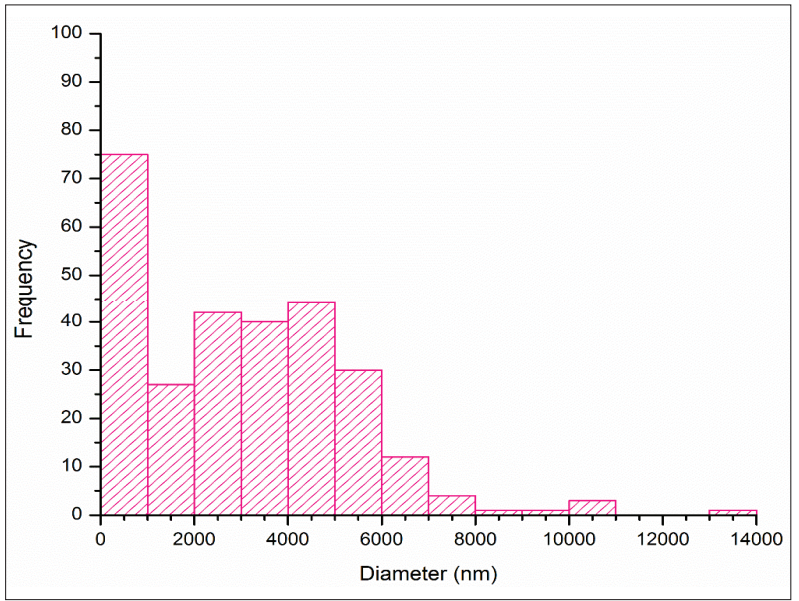

Figure 9: Pore diameter distribution of the modified TPFR system pore structure and their distribution. Hence, by controlling those factors we can obtain a high surface area and low density porous polymeric resin system (Szczurek et al., 2014).

\section{CONCLUSION}

Tannin obtained from the dried bark of Terminalia arjuna (Kumbuk) can be used to synthesise formaldehyde based resins with a considerable IEC. This value can be increased by the incorporation of phenol molecules that can impart extra flexibility to the polymer molecules. When changing the tannin to phenol ratio, IEC also increased with the highest value obtained in the 1:1 ratio resin system. Further, the IEC can be improved considerably by sulfonation using concentrated $\mathrm{H}_{2} \mathrm{SO}_{4}$. The highest adsorption capacity was shown by the sulfonated TPFR with tannin to phenol ratio of 1:1 for $\mathrm{Na}^{+}$, which was $1.552 \mathrm{meq} / \mathrm{g}$.

The formation of tannin formaldehyde, tannin phenol formaldehyde and its sulfonation was confirmed using FTIR spectra. When considering the swelling property, the lowest volume change of the resin was observed in the solution at $\mathrm{pH}$ 7. Stability of the resin system in all $\mathrm{pH}$ values was confirmed by the solubility test.

Synthesis of tannin-phenol-formaldehyde porous resin was carried out using coconut oil as the porogenic agent and hexamine as the crosslinker cum-catalyst. Its porous structure was confirmed by the SEM images. According to SEM images, the modified resin contained $\mu \mathrm{m}$ and $\mathrm{nm}$ scale pores, while the unmodified resin did not contain a clear porous structure. There were some closed cell structures in the modified porous resin and some of the open cell structures (windows) were 
embedded in large voids. According to FTIR spectra it confirms that the modified resin system is similar in the bond formation and polymerisation mechanism to the unmodified TPFR systems.

\section{REFERENCES}

1. Arasaretnam S. \& Karunanayake L. (2010). Synthesis, characterization, and metal adsorption properties of tannin phenol formaldehyde resins produced using tannin from dried fruit of Terminalia chebula (Aralu). Journal of Applied Polymer Science 115: 1081 - 1088.

DOI: https://doi.org/10.1002/app.31098

2. Garro Galvez J., Riedl B. \& Conner A. (1997). Analytical studies on tara tannins. Holzforschung-International Journal of the Biology, Chemistry, Physics and Technology of Wood 51: 235 - 243.

3. Kunin R., Meitzner E., Oline J., Fisher S. \& Frisch N. (1962). Characterization of amberlyst 15 macroreticular sulfonic acid cation exchange resin. Industrial and Engineering Chemistry Product Research and Development 1: 140 - 144 .

DOI: https://doi.org/10.1021/i360002a016

4. Mitra N., Banerjee R. \& Sarkar A. (1991). Studies on renewable polyphenol-based cation exchange resins of moderately high capacity. Journal of Applied Polymer Science 42: 2499 - 2508.

DOI: https://doi.org/10.1002/app.1991.070420915

5. Moubarik A., Charrier B., Allal A., Charrier F. \& Pizzi A. (2010). Development and optimization of a new formaldehyde-free cornstarch and tannin wood adhesive. European Journal of Wood and Wood Products 68: $167-177$.

DOI: https://doi.org/10.1007/s00107-009-0357-6

6. Ortiz Palacios J., Cardoso J. \& Manero O. (2008). Production of macroporous resins for heavy-metal removal. I. Nonfunctionalized polymers. Journal of Applied Polymer Science 107: 2203 - 2210.

DOI: https://doi.org/10.1002/app.27243
7. Özacar M., Soykan C. \& Şengil İ.A. (2006). Studies on synthesis, characterization and metal adsorption of mimosa and valonia tannin resins. Journal of Applied Polymer Science 102: 786 - 797.

DOI: https://doi.org/10.1002/app.23944

8. Pena C., De La Caba K., Retegi A., Ocando C., Labidi J., Echeverria J. \& Mondragon I. (2009). Mimosa and chestnut tannin extracts reacted with hexamine in solution. Journal of Thermal Analysis and Calorimetry 96: 515 521. DOI: https://doi.org/10.1007/s10973-007-8352-9

9. Randall J. (1977). Variations in effectiveness of barks as scavengers for heavy metal ions. Forest Products Journal 27(11): $51-56$.

10. Steyermark A. (1976). Spectrometric Identification of Organic Compounds (eds. R.M. Silverstein, G.C. Bassler \& T.C. Morrill), p. 340. Wiley, New York, USA.

11. Stuart B. (2005). Infrared spectroscopy. Kirk-Othmer Encyclopedia of Chemical Technology. Wiley Online Library.

12. Szczurek A., Fierro V., Pizzi A. \& Celzard A. (2014). Emulsion-templated porous carbon monoliths derived from tannins. Carbon 74: $352-362$.

DOI: https://doi.org/10.1016/j.carbon.2014.03.047

13. Yu H., Covey G.H. \& Oconnor A.J. (2008). Innovative use of silvichemical biomass and its derivatives for heavy metal sorption from wastewater. International Journal of Environment and Pollution 34: 427 - 450. DOI: https://doi.org/10.1504/IJEP.2008.020808

14. Zhang M. \& Sun Y. (2001). Cooperation of solid granule and solvent as porogenic agents novel porogenic mode of biporous media for protein chromatography. Journal of Chromatography 922: $77-86$.

15. Zhu J., Njuguna J., Abhyankar H., Zhu H., Perreux D., Thiebaud F., Chapelle D., Pizzi A., Sauget A. \& De Larminat A. (2013). Effect of fibre configurations on mechanical properties of flax/tannin composites. Industrial Crops and Products 50: 68 - 76. DOI: https://doi.org/10.1016/j.indcrop.2013.06.033 